\title{
Trapping Human Ribosomal Protein Genes
}

\author{
Jonathan R. Warner ${ }^{1}$ and Concepcion R. Nierras \\ Department of Cell Biology, Albert Einstein College of Medicine, Bronx, New York 10461 USA
}

\section{$\mathbf{T}$} he Ribosome

The proteins of all cells are assembled by the ribosome, the oldest molecular machine to have evolved in biological systems. Composed, in human cells, of four RNA molecules and 79 proteins, it is unchanged in function and nearly unchanged in structure during the $>2$ billion years that have passed since the separation of the eubacterial, archaebacterial, and eukaryotic kingdoms. Enormous efforts over the past 40 years have elucidated a strikingly detailed view of the structure and function of the Escherichia coli ribosome (for review, see Wilson and Noller 1998). Because of the basic conservation of the ribosome, it will be possible to extrapolate most of that structural and functional information to the mammalian ribosome.

The abundance of the four rRNA molecules led to an early determination of their sequences (Gonzalez et al. 1985; McCallum and Maden 1985). In contrast, the 79 ribosomal proteins are diverse, often insoluble, and can be identified only on the basis of their association with the ribosome. However, through a tour de force of technology and persistence, J.G. Wool, Y.-L. Chan, and colleagues (1995, and pers. comm.) have recently completed the sequence determination of the complete set of mammalian ribosomal proteins. Comparison with the sequence of the genome of Saccharomyces cerevisiae demonstrated that there is a close yeast homolog for all but one of the mammalian ribosomal proteins, demonstrating again the conservation of this machine during evolution.

\section{Mapping of Ribosomal Protein Genes}

In this issue of Genome Research, the Page laboratory reports another tour de force

\footnotetext{
${ }^{1}$ Corresponding author.

E-MAIL warner@aecom.yu.edu; FAX (718) 4308574.
}

of experimental design and persistence. Using the sequences provided by Wool et al. (1995), they have mapped 75 of the genes encoding human ribosomal proteins to positions on the human genetic map (Kenmochi et al. 1998). Fiftytwo of these are identified for the first time, and 22 are confirmations of previously reported map positions. This effort was challenging, because of the startling fact that for each ribosomal protein there is a single functional gene, but on average more than a dozen pseudogenes (Wiedemann and Perry 1984). The

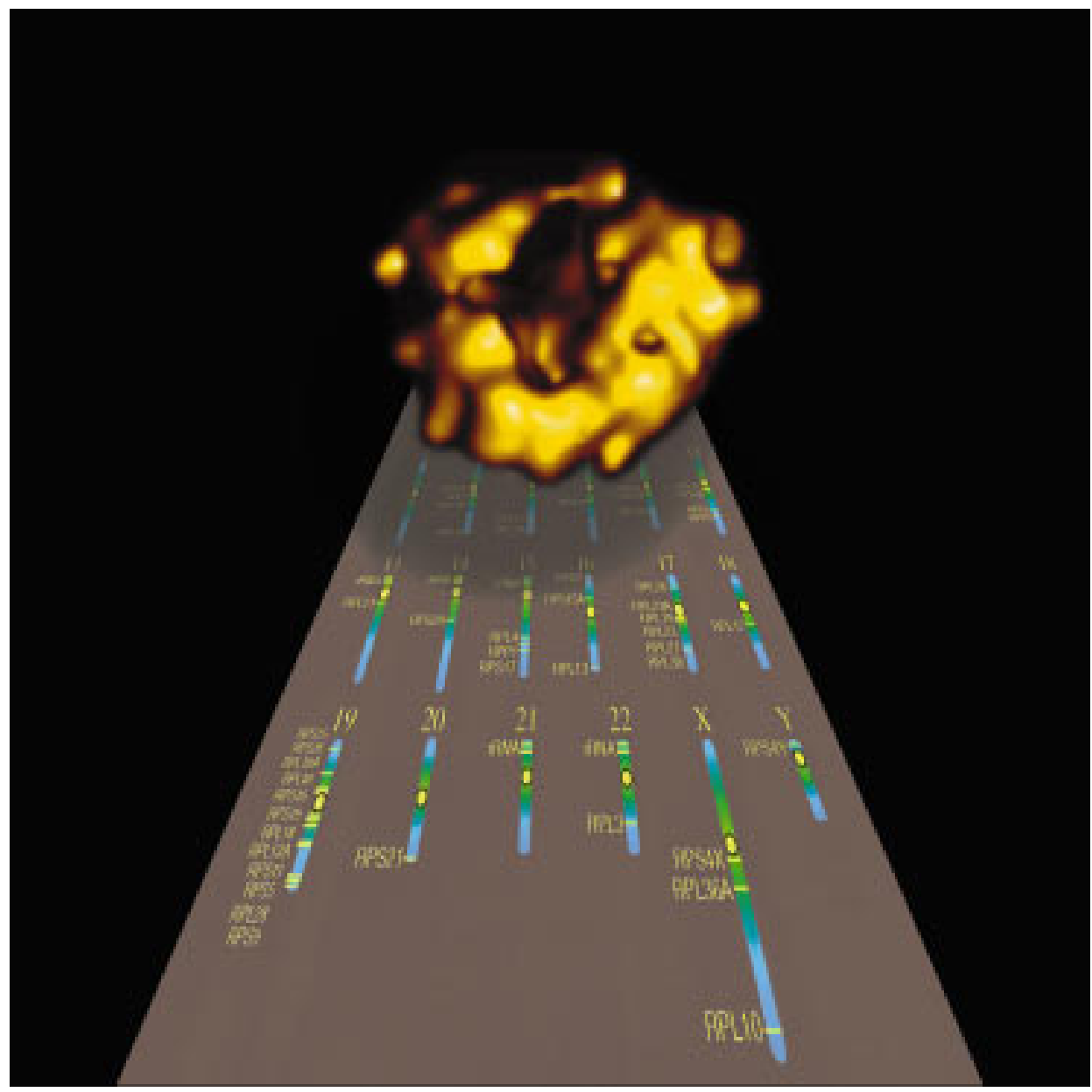

The mammalian ribosome (reconstructed by electron microscopy; courtesy of Joachim Frank) over map of ribosomal protein and RNA genes. (Courtesy of David Page, Tomoko Kawaguchi, and Jennifer Cook-Chaysos). pseudogenes have led to substantial confusion for mapping based on ESTs, as is evident from a search for "ribosomal protein" in the NCBI Human Gene Map. To overcome the problem of pseudogenes the Page group adapted and extended a method of intron-trapping (Davis et al. 1989) to identify sequences unique to each of the authentic ribosomal protein genes. Such sequence tags were then localized on the human genetic map by screening human-rodent hybrids, radiation hybrids, and YAC Iibraries. The human ribosomal protein 


\section{Insight/Outlook}

genes are widely scattered, being found on every chromosome except 7 and 21 . This is similar to the situation in Drosophila and in S. cerevisiae; the clustering of ribosomal protein genes into operons, characteristic of eubacteria and archaebacteria, is not apparent.

\section{Implications for Analysis of Genetic Diseases}

Before considering the potential role of ribosomal proteins in human disease, it is useful to consider aspects of ribosome synthesis that are unique. The ribosome is assembled in the nucleolus; once assembled, it persists, unlike, for example, the spliceosome, which is disassembled after each splicing event. Ribosome assembly probably occurs in a series of concerted reactions that requires a single copy of each of the ribosomal proteins. Thus, for lack of a single protein, the entire ribosome is lost. (Exceptions are the acidic proteins that are present in two that may not be assembled in the same way.) Furthermore, the malassembled ribosome may cause congestion in the nucleolus or release its ribosomal proteins to cause mischief else where in the nucleus. In the haploid S. cerevisiae, deletion of most of the ribosomal protein genes is lethal, although cells can survive the loss of L24 (L30 in the former yeast nomenclature) (Baronas et al. 1990) or L46 (Sachs and Davis 1990) but with substantially reduced growth rate. Therefore, we might expect full haploinsufficiency for a ribosomal protein gene to be a dominant lethal.

Yet, such is not the case. In Drosophila there are mutants at $>50$ loci, termed Minute, whose constellation of phenotypes includes delayed development, small body size, thin meager bristles, and reduced fertility (for review, see Kay and Jacobs-Lorena 1987). Initial suggestions that the Minute ${ }^{+}$genes might encode ribosomal proteins have been confirmed in a number of cases (Kongsuwan et al. 1985; Saeboe-Larssen et al. 1998). Thus, the Minute phenotype is due to haploinsufficiency of a single ribosomal protein gene, limiting the production of ribosomes; the severity of the phenotype is related to the degree of haploinsufficiency (Saeboe-Larssen et al. 1998). The phenotypic effects of multiple Minute mutations are not additive (Schultz 1929), consistent with the idea that ribosome assembly is a concerted process. It seems extraordinary that a fly with only half the normal production of ribosomes can develop at all, much less maintain some fertility.

The most obvious value of the mapped ribosomal protein genes is that they will provide candidates for the large numbers of genetic diseases with complex phenotypes that might be caused by the haploinsufficiency of a ribosomal protein gene. However, man is not a Drosophila, and it is not unlikely that complete haploinsufficiency for a ribosomal protein will alter the balance during development to such a degree that it is a dominant lethal mutation. The implication of this hypothesis is that the Page group has established 75 loci that cannot be deleted from the chromosome. This would identify important end points beyond which a deletion may not extend.

The interest of the Page laboratory in ribosomal protein genes arose from their hypothesis, still somewhat controversial, that Turner's syndrome is due to a haploinsufficiency of the ribosomal protein S4, for which there are genes on both the $X$ and the $Y$ chromosomes (Fisher et al. 1990). RPS4X escapes X inactivation, but there may be insufficient S4 protein in individuals with an XO genotype. Interestingly, there are two other ribosomal protein genes that re side solely on the $X$ chromosome, RPL10 and RPL36a (van den Ouweland et al. 1992; Oeltjen et al. 1995). To provide equimolar amounts of these proteins, these genes must be twice as active as the rest of the ribosomal protein genes.

Although trisomies for chromosomes carrying ribosomal protein genes are not uncommon, the overproduction of a ribosomal protein is less likely to be a serious problem for the organism, as there are mechanisms for the rapid turnover for ribosomal proteins that are not assembled into ribosomes (Warner 1977).

Finally, mutant alleles of ribosomal proteins can have profound effects on translation and, therefore, on gene expression. This is most apparent in the mutant forms of several ribosomal proteins, for example, S2, S9, and S23 (encoded by SUP44, SUP46, and RPS28 in $\mathrm{S}$. cerevisiae) that are implicated in codon-anticodon accuracy (Hinnebusch and Liebman 1991; Alksne et al. 1993). Although these have as yet only been identified in lower eukaryotes, it is likely that the subtle effects of such alleles in man will be recognized in years to come.

\section{Implications for Gene Fusion Diseases}

The trk-2h oncogene, isolated from a human breast tumor line, is a fusion of the upstream sequences and 41 codons of the RPL 7a gene with a portion of the trk proto-oncogene receptor kinase domain (Ziemiecki et al. 1990). Although the biochemical implications of this fusion are not clear, it reminds us that fusion of a ribosomal protein gene to a "hot" gene could bring about disease in at least three ways. (1) The ribosomal protein genes are rather actively transcribed; fusion of such a promoter to an oncogene could lead to its unregulated expression. (2) Ribosomal proteins have nuclear localization signals; fusion with another protein could bring that protein to the nucleus in an untimely manner. (3) Ribosomal proteins are generally very basic and tend to bind nucleic acids, especially RNA; fusion to another protein could lead to an untimely juxtaposition of that protein to RNA or DNA.

\section{Control of Cell Growth}

Much attention is now paid to the role of a variety of oncogenes, signal transduction pathways, and so forth, in controlling cell growth. Far less attention is paid to the pedestrian activities needed to support cell growth, of which the synthesis of ribosomes is paramount. Although a substantial proportion of the control of ribosomal protein synthesis occurs at the level of translation (Meyuhas et al. 1996), ultimately the coordinated transcription of the 79 ribosomal protein genes must be responsive to growth stimuli. Growing cells need new ribosomes. Indeed, certain colon cancers have substantially increased levels of all ribosomal protein mRNAstested (PogueGeile et al. 1991). The decline in ribosomal protein mRNA levels during senescence may reflect the converse phenomenon (Seshadri et al. 1993). Although enhancer/promoter sites in the upstream region and in the first intron of ribosomal protein genes have been identified (Chung and Perry 1993; Safrany and Perry 1995), we are far from understanding transcription control. Now that the authentic genes encoding these 75 ribosomal proteins have been 
identified, analysis of the potential regulatory sequences may reveal common features that will lead to an understanding of the basis for the coordinate transcription of this class of genes and may suggest methods for intervention to inhibit tumor growth.

Finally, before basking too contentedly in the accomplishments of the Page laboratory, we should remember that an entire set of mitochondrial ribosomal protein genes awaits mapping. These are likely to be nearly as important to the cell as are the cytoplasmic ones.

\section{ACKNOWLEDGMENTS}

We are grateful to Marcelo Jacobs-Lorena, Rajy Kucherlapati, Bernice Morrow, Anne Puech, and Ira Wool for useful discussions.

\section{REFERENCES}

Alksne, L.E., R.A. Anthony, S.W. Liebman, and J.R. Warner. 1993. Proc. Natl. Acad. Sci. 90: 9538-9541.

Baronas Lowell, D.M. and J.R. Warner. 1990. Mol. Cell. Biol. 10: 5235-5243.

Chung, S. and R.P. Perry. 1993. Nucleic Acids Res. 21: 3301-3308.

Davies, B., S. Feo, E. Heard, and M. Fried. 1989. Proc. Natl. Acad. Sci. 86: 6691-6695.

Fisher, E.M., P. Beer-Romero, L.G. Brown, A. Ridley, J.A. McNeil, J.B. Lawrence, H.F. Willard, F.R. Bieber, and D.C. Page. 1990. Cell 63: 1205-1218.

Gonzalez, I.L., J.L. Gorski, T.J. Campen, D.J Dorney, J.M. Erickson, J.E. Sylvester, and R.D. Schmickel. 1985. Proc. Natl. Acad. Sci. 82: 7666-7670.

Hinnebusch, A.G. and S.W. Liebman. 1991. In The molecular and cellular biology of the yeast Saccharomyces: Genome dynamics, protein synthesis, and energetics (ed. J.R. Broach et al.), pp. 627-735. Cold Spring Harbor Laboratory Press, Cold Spring Harbor, NY.

Kay, M.A. and M. Jacobs-Lorena. 1987. Trends Genet. 3: 347-351.

Kenmochi, N., T. Kawaguchi, S. Rozen, E. Davis, N. Goodman, T. Hudson, T. Tanaka, and D. Page. 1998. Genome Res. (this issue).

Kongsuwan, K., Q. Yu, A. Vincent, M.C. Frisardi, M. Rosbash, J.A. Lengyel, and J. Merriam. 1985. Nature 317: 555-558.
McCallum, F.S. and B.E. Maden. 1985. Biochem. J. 232: 725-733.

Meyuhas, O., D. Avni, and S. Shama. 1996. In Translational control (ed. J.W.B. Hershey et al.), pp. 363-388. Cold Spring Harbor Laboratory Press, Cold Spring Harbor, NY.

Oeltjen, J.C., X. Liu, J. Lu, R.C. Allen, D. Muzny, J.W. Belmont, and R.A. Gibbs. 1995. Mamm. Genome 6: 334-338.

Pogue-Geile, K., J.R. Geiser, M. Shu, C. Miller, I.G. Wool, A.I. Meisler, and J.M. Pipas. 1991. Mol. Cell. Biol. 11: 3842-3849.

Sachs, A.B. and R.W. Davis. 1990. Science 247: 1077-1079.

Saeboe-Larssen, S., M. Lyamouri, J. Merriam, M.P. Oksvold, and A. Lambertsson. 1998. Genetics 148: 1215-1224.

Safrany, G. and R.P. Perry. 1995. Eur. J. Biochem. 230: 1066-1072.

Schultz, J. 1929. Genetics 14: 366-419.

Seshadri, T., J.A. Uzman, J. Oshima, and J. Campisi. 1993. J. Biol. Chem. 268: 1847418480.

van den Ouweland, A.M., P. Kioschis, M. Verdijk, F. Tamanini, D. Toniolo, A. Poustka, and B.A. van Oost. 1992. Hum. Mol. Genet. 1: 269-273.

Warner, J.R. 1977. J. Mol. Biol. 115: 315-333.

Wiedemann, L.M. and R.P. Perry. 1984. Mol. Cell. Biol. 4: 2518-2528.

Wilson, K.S. and H.F. 1998. Cell 92: 337-350.

Wool, J.G., Y.-L. Chan, and A. Gluck. 1995. Biochem. Cell. Biol. 73: 933-947.

Ziemiecki, A., R.G. Muller, F. Xiao-Chang, N.E. Hynes, and S. Kozma. 1990. EMBO J. 9: 191-196. 


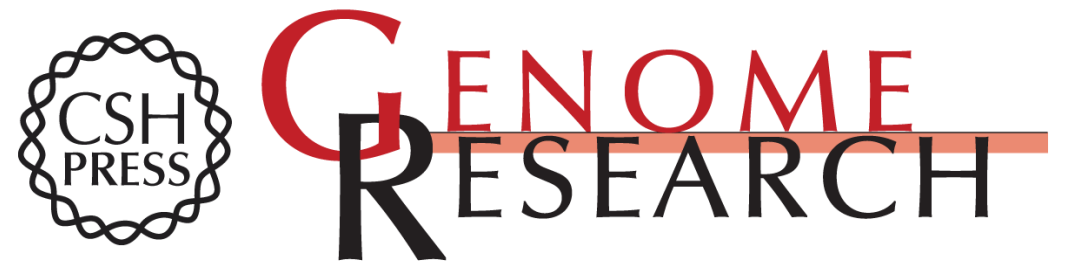

\section{Trapping Human Ribosomal Protein Genes}

Jonathan R. Warner and Concepcion R. Nierras

Genome Res. 1998 8: 419-421

Access the most recent version at doi:10.1101/gr.8.5.419

References This article cites 21 articles, 11 of which can be accessed free at:

http://genome.cshlp.org/content/8/5/419.full.html\#ref-list-1

\section{License}

Email Alerting Receive free email alerts when new articles cite this article - sign up in the box at the Service top right corner of the article or click here.

\section{Affordable, Accurate Sequencing.}

To subscribe to Genome Research go to:

https://genome.cshlp.org/subscriptions 